\title{
E-government in the Era of Globalization and the Health Crisis caused by the Covid-19 Pandemic, between Standards and Innovation
}

\author{
Sorin Burlacu ${ }^{*}$, Simona Roxana Patarlageanu ${ }^{1}$, Amelia Diaconu ${ }^{2}$, and Ghenadie Ciobanu ${ }^{3}$ \\ ${ }^{1}$ Bucharest University of Economic Studies, 6 Piata Romana, Bucharest, Romania \\ ${ }^{2}$ Artifex University, Strada Economu Cezărescu 47, Bucharest, Romania \\ ${ }^{3}$ INCSMPS, Str. Povernei 6-8, Bucharest, Romania
}

\begin{abstract}
.
Research background: E-government has started from the challenges of new technologies by providing e-services to its citizens and has expanded today in more and more fields, including communication with citizens, budget management, macroeconomic forecasts, etc. If we accept the definition according to which eGovernment (or e-government) is an applicability of information technology for the provision of administrative services, information exchange, communication transactions, integration of various electronic systems and autonomous services between government and citizen (G2C), government and business environment (G2B), government and government $(\mathrm{G} 2 \mathrm{G})$ as well as for the processes and interactions of administrative staff in the entire infrastructure of the administration, and through e-government, government services are available to citizens in a convenient, efficient and transparent way, then we will accept and the conclusions of the same research that considers that in e-government there are no identifiable barriers.

Purpose of the article: Through this paper we aim to highlight the current economic realities and how some governments have understood to use technology during the pandemic.

Methods: The research methodology is based on documentary analysis. The bibliographic study, the secondary analysis of the data, the observation and the analysis complete the documentary analysis and allowed us to obtain some conclusive results.

Findings \& Value added: The pandemic health crisis has further pushed the limits of technology, which has been transformed into a true universal panacea for solving relatively vital economic activities for a national economy in a global context. A first finding was that the pandemic accelerated the need for digital governance. However, the modalities of action remain open.
\end{abstract}

Keywords: e-government; globalization; health crisis; innovation

JEL Classification: $H 11 ; I 38 ; N 4$

* Corresponding author: sburlacu@amp.ase.ro 


\section{Introduction}

One of the fundamental dimensions of the information society is part of the politicaladministrative aspect, this being the way in which public bodies streamline their activities related to citizens and ensure democracy in the digital age [1-3]. Public administration and, implicitly, the central component of structuring and governance in society, must provide a favourable framework for community development and provide citizens with diverse and detailed public services [4-7].

The Romanian Public Administration is in the midst of an ongoing modernization and restructuring, so as to align, from an ICT point of view, with the recommendations of the European Union, published in documents such as the "Digital Agenda for Europe", which is one of the main objectives of the Europe 2020 Strategy, which aims to train ICT as the main engine for achieving the 2020 targets. Public sector employees need to adapt to the requirements of the Digital Agenda for Europe, to develop digital skills and inclusion, by achieving their services close to the citizens and meeting the objectives of efficiency, democracy and transparency. Although, in Romania this process of modernization of began now more than 30 years, namely in 1989, the government still encounters the following problems [8]:

- Lack of interest and fear of change;

- Reduced perception of the response of citizens and partners;

- Failure to comply with recent technological advances;

- Insularity - employees want to be creative and think ahead;

- Staff deficiencies and lack of experts in the field.

It is also very important to reduce the digital divide, defined as "the difference between people who have knowledge in the field of information technology and who have access to information resources, such as the Internet, and those who do not" [9-10]. It is suggested that most of the time the reason for the failure to implement an e-government system is given by the fact that the focus is on the technological side, thus losing sight of the governance component. It proposes a methodology to determine the purpose, performance, expectations from management, implementation of the architecture, but also the technology of permanent monitoring [11]. Thus, it will be able to achieve a high degree of efficiency, being one step closer to excellence.

Another key principle of e-government emphasizes impartiality, non-discrimination, integration and last but not least, objectivity. This means that the public institution must ensure equal treatment for all citizens and eliminate any arbitrary actions, with an emphasis on equity. For the development of e-government, a critical criterion is the orientation towards citizens, this representing a desideratum for an institution that aims to satisfy the needs of citizens [12].

\section{Research background}

In Romania, according to Law 52/2003 on decisional transparency in public administration, there are lists of objectives: developing the degree of responsibility of public administration towards citizens who benefit from the administrative decision and in drafting normative acts.

E-government should provide information available online as well as interactive access, including the ability to conduct transactions that target, for example, the payment of taxes and duties [13]. These things must take place in a perfectly secure context. For this system to work and be accessible to everyone, it must be easy to use. Equally important is the seamless integration into the organizational system specific to public institutions, so that they can interact and should not be forced to turn to secondary sources of information. 
There are 5 steps to implementing e-government in practice, as follows:

- Step 1: Create web pages for each institution, containing general information;

- Step 2: Extending the coverage of information, the appearance of online publications and the possibility of contacting the institution by the citizen by e-mail;

- Step 3: Enter online forms for download and other facilities;

- Step 4: The ability of citizens to vote online and obtain various documents, such as a passport or driver's license. Also, the introduction of the possibility to make payments online;

- Step 5: Expanding the range of services offered to citizens through the Internet.

If the state has the 5 steps implemented above, the level of transparency is higher, as an

IT system is not subjective, it will not be able to discriminate or make any kind of concession, the rules being applied to each taxpayer. Automatically, such a system implemented in accordance with legal and moral norms, will gain the trust of the population, they feel the justice and fairness of the entire system and, thus, will encourage the relationship with the state. In other words, citizens' approaches were the starting point and purpose of the e-government concept. The information allows citizens, on the one hand, to appreciate the informed actions of the administration and, on the other hand, to participate in debates and informed decisions about them.

According to international studies on e-government barriers to the implementation of egovernment solutions are both technical and non-technical, with the vast majority being people and processes and organizations, rather than technological. An analysis of the success factors of e-government in developing countries identified 6 success factors:

- Changes in the work process

- Technical / human resources

- Organizational culture and values

- Vision and internal strategy / leadership

- External financial support

- Laws, regulations and policies

There are therefore many factors that can lead to the failure of e-government projects, for example, unchanged government structures, technical barriers, lack of IT training for civil servants.

\section{Purpose of the article}

The problem of developing e-government in local public administration in Romania involves multiple agreements that require an integrated approach. The factors that determine the development of e-government are both related to the institutions that should make e-government available to services.

Through this paper we aim to highlight the current economic realities and how some governments have understood to use technology during the pandemic

\section{Methods}

The research methodology is based on documentary analysis. The bibliographic study, the secondary analysis of the data, the observation and the analysis complete the documentary analysis and allowed us to obtain some conclusive results. 


\section{Results and discussion}

In terms of public administration, the development of e-government solutions at the local level depends on the financial, technical and human resources that a local institution is prepared to use, but moreover, there must be interest from the management.

Despite the continuing decline in e-equipment prices, in particular the lack of financial resources amid budgetary austerity in recent years due to the economic crisis, there are still problems, the crisis being considered at the time the biggest cause of the limitation of egovernment local. The greater polarization among the local communities in Romania, makes the small and poor communities to focus more on socio-economic projects, i.e. on problems to which the solution cannot be solved through a computer, thus, the implementation of e-government takes second place in among these communities.

In terms of human resources, although many programs have been developed in recent years to increase the digital competence of civil servants, many of them have no knowledge of the e-government system, the available technology is quite old and the understanding of its capacity is quite reduced. The traditional way of working for any job and every position in public administration is structured, and most civil servants prefer to continue to use this traditional way of working, based on the fact that e-government is the prerogative of IT specialists. Among IT departments in public administration, there are too few specialists due to low salaries compared to the private sector. In general, people in these departments face the current management system as supporters of the public service. In the Romanian public sector, the function of Chief Information Office (CIO) does not exist, in the public administration sector and IT department managers do things that normally a CIO should not do, for example, network management, most being involved in the strategic decisions of the institution. Every time changes are organized, everything that has been done by staff with years of experience is deleted and new ideas are introduced, but unfortunately, they are not always good for the computer system.

Resistance to change in public institutions is considerable, and civil servants and management are generally very reluctant to take e-government initiatives, which in many cases involve rethinking processes at the institutional level, creating new roles, redefining responsibilities, increasing tasks, namely those that effectively affect the functioning of the institution.

At the same time, the adoption of the vast majority of e-government solutions in Romania at the central level, clearly showed the institutions that they should manage and benefit from them, knowing that the initiatives that come from public authorities and are supported by the will politics, they are most likely ready to succeed. For example, the implementation of one of the most sophisticated e-government services in Romania, more precisely, the payment of taxes online, has been very little used due to the identification of local needs. The e-government systems developed by local authorities have in many cases involved copying similar systems of other authorities, often offering generic solutions, inappropriate at the local level and to the needs and requirements of citizens. Traditionalism in the provision and use of government services, a traditionalism that characterizes public administration, but also its beneficiaries, is therefore an important limit for the development of e-government solutions at the level of local public administration in Romania. At the moment, any business or civil society in Romania does not exert enough influence to move from traditional governance to e-government. This is also due to digital differences that divide Romania from most Member States of the European Union. 


\section{1 e-Government during the Coronavirus Pandemic (COVID-19)}

More and more researchers conclude that the disturbance induced by COVID-19 will be studied by social scientists, psychologists and historians for years to [14]. Beyond the search for solutions, researchers agree that government, in particular, must operate in a world of increasing complexity. a possible key to success is collaboration between all sectors and members of society [15]. In this way, governments, companies and citizens will be able to successfully face the challenges of a global economy that comes with global risks, such as pandemic ones [16].

An initiative to combat the COVID-19 pandemic of some governments has launched call services (e.g. Pakistan number is 1166) and a website specially designated for the public (e.g. Pakistan https://covid.gov.pk/). They provide an up-to-date analysis of the situation in order to raise awareness of preventive measures against COVID-19. Moreover, several governments are regularly launching awareness messages and measures via mobile SMS [17].

In fact, more and more opinions compare the COVID-19 pandemic with wartime and try to highlight, as much as possible, positive aspects of this situation such as stimulating innovation (Medeiros et al., 2020) or prompt responses through virtual solutions and platforms to help digitize social life, as a weapon in the "War on COVID-19" $[18,19]$. Some studies have also shown an increase in online social presence around the world during the pandemic due to measures imposed by authorities such as social isolation or quarantine [20].

Other research has focused on investigating the readability and presence of translated online information available to a specific audience during COVID-19. Their findings were that the readability of COVID-19 information would be below national standards and that there would be a lack of translated and graphic accompanying materials online which could lead to an increased level of misunderstanding about the COVID-19 pandemic and the decisions taken [21]. Some researchers wanted to present data sets that provide information about this pandemic, in response to the global demand for data to understand COVID-19 from a specific country (e.g. Vietnam) [22] or an administrative region (e.g. Macao) [23]. Other research examines important factors that influence citizens 'satisfaction with their governments' responses to the COVID-19 pandemic based on a survey conducted in several countries [24].

In Romania, after the official declaration of a pandemic by the WHO, the government took a series of measures to combat it including are encouraging area citizens their use online means of payment. Payments due by citizens or companies to the Romanian state are made through Ghișeul.ro, a platform managed by the Romanian Digitization Authority and APERO - the Association for Electronic Payments in Romania. Site authority is says that $\mathrm{d}$ is the beginning of the year, over 207,000 users have registered on www.ghiseul.ro, the highest number since the launch of this service (the year of release was in 2011). At the same time, it is also specified that starting with January of this year, 679,587 payments were made through the platform, given that a total of 484,824 payments were made throughout 2019 and the period January - August 2020, the total number of revenues exceeded 317 million lei, double the total revenues in 2019. In fact, $p$ is 50 new types of payments were added recently, as a result of the interconnection with the Virtual Private Space administered by ANAF and by adding the possibility of to pay for new public services such as public transport, sanitation, thermal energy, water or sewerage. Government of Romania hope it's not soon to be able to be paid and the value of passports, registration certificates, permits and provisional driving licenses. In the meeting of the Romanian Government on Friday, August 14, a Decision was adopted whose 
provisions supplement the categories of services whose payment can be made through the online platform Ghișeul.ro, administered by the Authority for the Digitization of Romania. Theoretically, the Romanian government states that all types of payments related to the provision of any public service can be made electronically, including any community service of public utility, as well as all types of payments related, directly or indirectly, to the provision of that service. For those institutions, which do not have their own online registration system, the platform aici.gov.ro was created, as an intermediary for registration documents to respond to citizens' requests in electronic format as soon as possible. This platform was recently used for submitting documents to the National Agency for Payments and Social Inspection of Romania for requesting the indemnity according to OUG (Government Emergency Ordinance) no. 30/2020 that stable it measures social protection in the context of the epidemiological situation caused by the spread of coronavirus SARSCoV-2.

At EU level, an answer to the question COVID-19: How eGovernment and trust services can help citizens and businesses has been given since March 2020. The European Commission stated on its website ec.europa.eu that when face-to-face interaction is impossible (in the sense of citizens complying with government recommendations for social distancing), e-government solutions become vital and citizens must not leave their homes to interact with public administrations, they must not meet face to face thanks to trusted agents "EID" and eSignature CEF Building Blocks and, in general, eIDAS regulation.

Internationally, the OECD (Organization for Economic Co-operation and Development) announces on its website oecd.org that in April 2020, the OECD Digital Governance and Data Unit, together with GovLab from NYU, launched a joint call for evidence on the release and use of open government data (OGD) by various actors (such as entrepreneurs, media, researchers, CSOs and the public sector) in response to the COVID-19 pandemic.

\section{Conclusions}

In conclusion, a first recommendation would be that all e-government solutions that are implemented and integrated in a unitary system with appropriate links and connections to achieve compatibility of collaboration and information processing, both within the same institution and between central authorities and local and local between local municipalities and other public institutions. Given the current level of development of e-government in Romania, the main difficulty will be the integration of local initiatives already implemented with ongoing national strategies. The multitude and complexity of legal regulations, and in particular with regard to the protection of citizens' privacy and data security, could be obstacles to the implementation of e-government.

The introduction of new technologies in public administration is a very important step for the modernization of society and this is due to the benefits they offer. An advantage of e-government refers to the reduction of expenses, firstly, those related to salaries, and secondly, expenses related to the maintenance of offices. Another advantage is the optimization of citizens' access to public information and services. Reducing costs and reducing the time spent at the counter, both for citizens and authorities, is another important advantage, the need to move citizens to the headquarters of public institutions, being eliminated, they are able to access public information from home or from any another place. In the short term, in the context of the COVID-19 pandemic, it is a measure that comes to support social distance as the main measures to combat the spread of the virus and implicitly the disease due to it. 
The relationship between citizens and authorities can be improved through e-government, and citizens are satisfied that they have access to all public information, thus increasing their involvement in the governance process.

However, according to the study conducted in this paper, e-government does not enjoy the same popularity at the local level, citizens are not informed about the possibility of implementing such a system. The problem starts from the level of acceptance of the citizens, but also from the fear of changing public institutions. In addition, the problem may come from the working style of civil servants, who are not willing to change.

The implementation of new technologies in public administration also has some disadvantages, but they are insignificant compared to the advantages it offers.

Therefore, the e-government model can positively influence the public administration and the citizens' environment.

\section{References}

1. Androniceanu, A., Burlacu, S., Drăgulănescu, I. V., Nicolae, E. E. (2017). New trends of businesses digitalization in Romania and the behaviour young consumers. In $\mathrm{V}$. Dinu (Ed.), BASIQ International Conference: New Trends in Sustainable Business and Consumption (pp. 27-35). Graz

2. Baker, D. L. (2011). Designing and Orchestrating Online Discussions. MERLOT Journal of Online Learning and Teaching, 7(3), 401-411.

3. Burlacu, S., Alpopi, C., Mitrită, M., Popescu, M. L. (2019). Sustainable e-Governance and Human Resource Development. European Journal of Sustainable Development, 8(5), 16.

4. Burlacu, S. Jiroveanu, D. C. (2009). IT Governance and Educational Ideal. Administratie si Management Public, 13, 73-82.

5. O'Keefe, D. J. (2002). Persuasion: Theory and Research. SAGE Publications.

6. Filip, M., Grama, C. V. (2005). Tehnologii informationale pentru administratia publica: lucrari practice si teste grila. Iasi: Sedcom Libris Publishing House.

7. Gasova, K., Stofkova, K. (2017). E-Government as a quality improvement tool for citizens' services. Procedia Engineering, 192, 225-230.

8. Profiroiu, A. (2010). Bazele administrației publice. Bucharest: Economica Publishing House.

9. Rădulescu, C. V., Bodislav, D. A., Burlacu, S. (2018). Demographic Explosion and IT Governance in Public Institutions. Managerial Challenges of the Contemporary Society, 11(1), 18-22.

10. Sandor, D. S. (2006) Romania's Digital Divide and the Failures of E-Government. Transylvanian Review of Administrative Sciences, 16E, 154-162.

11. Rieh, S. Y., Hilligoss, B. (2008). College Students' Credibility Judgments in the Information Seeking Process. In M. J. Metzger \& A. J. Flanagin (Eds.), Digital Media, Youth, and Credibility. Cambridge: The MIT Press.

12. Stoica, V., Ilaş A. (2009). Romanian Urban e-Government. Digital Services and Digital Democracy in 165 Cities. Electronic Journal of e-Government, 7(2), 171-182.

13. Urs, N. (2017). E-government Services in Romanian Cities: A Look from the Inside. CEE e|Dem and e|Gov Days 2017, 533-543.

14. Foss, N. J. (2020). Behavioral Strategy and the COVID-19 Disruption. Journal of Management, 46(8), 1322-1329.

15. Coe, A., Paquet, G., Roy, J. (2001). E-Governance and Smart Communities: A Social Learning Challenge. Social Science Computer Review, 19(1), 80-93. 
16. Ullah, A., Pinglu, C., Ullah, S., Abbas, H. S. M., Khan, S. (2020). The Role of EGovernance in Combating COVID-19 and Promoting Sustainable Development: A Comparative Study of China and Pakistan. Chinese Political Science Review, 1-33.

17. Medeiros, B. P., Goldoni, L. R. F., Batista Junior, E., Rocha, H. R. D. (2020). O uso do ciberespaço pela administração pública na pandemia da COVID-19: diagnósticos e vulnerabilidades. Revista de Administração Pública, 54(4), 650-662.

18. Bennet, B., Berenson, T. (2020, March). As Coronavirus Spreads, Trump Refashions Himself as a Wartime President. Time. Retrieved from : https://time.com/5806657/donald-trump-coronavirus-war-china/

19. Nienaber, M., Carrel, P. (2020, March). Merkel tells Germans: Fighting virus demands war-time solidarity. Reuters. Retrieved from : https://www.reuters.com/article/ushealth-coronavirus-germany-idUSKBN2153GX

20. Yasir, A., Hu, X., Ahmad, M., Rauf, A., Shi, J., Ali Nasir, S. (2020). Modeling Impact of Word of Mouth and E-Government on Online Social Presence during COVID-19 Outbreak: A Multi-Mediation Approach. International Journal of Environmental Research and Public Health, 17(8), 2954.

21. Khan, S., Asif, A., Jaffery, A. E. (2020). Language in a Time of COVID-19: Literacy Bias Ethnic Minorities Face During COVID-19 from Online Information in the UK. Journal of Racial and Ethnic Health Disparities.

22. Tung, L. T., Thanh, P. T. (2020). Survey data on government risk communication and citizen compliance during the COVID-19 pandemic in Vietnam. Data in Brief, 33, 106348 .

23. Loi, K. I., Lei, W. S., Lourenço, F. (2020). Understanding the reactions of government and gaming concessionaires on COVID-19 through the neo-institutional theory - The case of Macao. International Journal of Hospitality Management, 102755.

24. Chen, C. W. S., Lee, S., Dong, M. C., Taniguchi, M.. (2020). What Factors Drive the Satisfaction of Citizens on Governments' Responses to COVID-19?. International Journal of Infectious Diseases. 